\title{
Effect of frequency of pasture measurement on estimation of pasture growth rates: field observations and predictions of a whole farm model
}

\author{
W.E. PREWER, J.A. LILE, K.A. MACDONALD, K.P. BRIGHT, C.C. PALLISER, \\ J.A.S. LANCASTER and M.E.WASTNEY \\ Dexcel, Private Bag 3221, Hamilton \\ warwick.prewer@dexcel.co.nz
}

\begin{abstract}
The frequency of measurements to generate pasture growth rate data varies. Commonly measurements are made once weekly or fortnightly and averaged monthly, using a variety of methods. To assess the effect of frequency of measurement on estimates of pasture growth rate, weekly visual assessment of farm pasture cover was compared with the fortnightly and monthly average and also with predictions by a Whole Farm Model. Weekly observed pasture growth rates had large fluctuations but these were removed when the weekly values were averaged monthly. The fluctuations are due to the variety of paddocks assessed, climatic factors, inconsistencies of operators and inherent errors in the technique used. Values calculated by a Whole Farm Model also showed daily variation in pasture growth rate but the fluctuations were not as severe as those in the observed pasture growth rate data because human error of assessment and error in the technique were removed. Observed monthly pasture growth rates were also compared with values calculated by the model. The model closely predicted observed pasture growth rates for most months. To obtain an accurate estimate for monthly growth rates it is better to average a number of assessments. In the field, this could be an average of weekly observations. Because the model calculates rates daily, it can be used to predict pasture growth rates on a more frequent basis (e.g. weekly) to aid feed budgeting. Keywords: dairy farm, herbage mass, model, pasture growth, simulation
\end{abstract}

\section{Introduction}

Variation in pasture growth is a result mainly of climate and soil fertility and tends to be greatest in late spring, summer and early autumn (Roberts \& Thomson 1984). Thus a tool that predicts likely changes in pasture growth for different climatic conditions over this period would aid grazing management on dairy farms.

Pasture growth rate is commonly determined weekly, fortnightly or monthly, using a variety of methods such as the rising plate meter, visual assessment and cutting pasture in cages. When used as part of a farm pasture assessment, the rising plate meter cannot be relied upon to give useful results for pasture growth (net herbage accumulation), due to its under-estimation of herbage mass (Lile et al. 2001) and over-estimation of post-grazing mass (Thomson et al. 2001). The rising plate meter can be used in conjunction with cages to generate reliable pasture growth rate data for dairy farms, as described by Davis et al. (1998). There is a reluctance to use cages due, in the main, to the high workload required. Visual assessment of pasture cover is therefore more widely used to generate pasture growth rate data (Piggot \& Morgan 1985).

Several computer models that simulate pasture production in New Zealand, using climate and soil fertility inputs have already been developed. Examples include McCall (1984), Baars \& Rollo (1987), Woodward (1999) and Moir et al. (2000). To date, there has been little validation of such models by comparison of predicted pasture growth rate data with observed data for a variety of regions and climates. Dexcel is developing a computer model, the Whole Farm Model (WFM), for dairy researchers to simulate farm system trials (Bright et al. 2000). The WFM uses published component models for cow metabolism and pasture growth (net herbage accumulation) linked within a framework. A recent test of the WFM's validity for milk production and pasture production in different New Zealand regions showed that the model tended to over-predict annual growth (5-57\%) especially during spring-early summer. Differences in frequency of pasture growth measurement between the observed data (weekly, ten daily and monthly) and the WFM (daily and averaged monthly) may explain some of the variation between the observed data and the WFM predictions (Lile et al. 2002; Wastney et al. 2002). The purpose of this study was to assess the effect of the frequency of pasture measurement on estimation of pasture growth rates using field observations and WFM predictions for a variety of frequencies of measurement.

\section{Method}

Pasture growth rate data for the Waikato were calculated from weekly visual estimates of pasture cover for nongrazed paddocks, from a farmlet stocked at 3.2 cows /ha in the Whole Farm Efficiency trial (Macdonald et al. 2001) at Dexcel No 2 Dairy, Ruakura during the 1999-00 season. The weekly visual estimates were calibrated using eleven $0.3 \mathrm{~m}^{2}$ quadrats cut to ground level using a sheep shearing handpiece. Between two and four people 
visually assessed each quadrat and gave an estimate of the $\mathrm{kg}$ DM equivalent per hectare in each quadrat. The cut herbage was washed to remove dirt and faeces from the sample, oven dried for 48 hours at $95-100^{\circ} \mathrm{C}$, and weighed. The weighed data from each plot were regressed against the average visual assessment of the assessors. The regression equation that was formed was used to alter the visual assessment for each paddock and calibrate the assessors for future pasture assessments. The net herbage accumulation (pasture growth) was calculated weekly from the increase in herbage mass on ungrazed paddocks (Macdonald et al. 2001). The weekly pasture growth rates were averaged fortnightly and monthly.

The WFM was set up to run simulations for the 1999-00 season in the Waikato. Information on animals, land, climate and a management policy were entered. Animals used for each simulation consisted of individual cows over a normal age and liveweight range. Information for the land included paddocks, area, and the initial pasture cover for each paddock. A management policy based on a set of decision rules (Macdonald \& Penno 1998) was used. Climate data specific for the year were obtained from NIWA sites at Ruakura (less than $1 \mathrm{~km}$ from Dexcel No2 Dairy). The animal component model used was an in-house energy-based cow model (not published), and the pasture growth model was the McCall (1984) model.
The McCall (1984) model calculates daily net herbage accumulation based on climate, residual cover, and whether the pasture has been grazed, cut, or topped. The daily values were averaged weekly, fortnightly and monthly. Average pasture growth rate values from the WFM were then compared with the averaged monthly observed values.

\section{Results}

Observed pasture growth rates had large fluctuations when rates were determined based on one weekly observation (Figure 1). For example, values ranged from $171 \mathrm{~kg} \mathrm{DM} /$ ha/day for the week ending $10 \mathrm{Jan}$ to $-115 \mathrm{~kg} \mathrm{DM} / \mathrm{ha} /$ day for the following week. These large fluctuations were less apparent when the weekly

Table 1 Seasonal distribution of pasture growth and standard errors at Ruakura Dexcel No 2 Dairy.

\begin{tabular}{lcccc}
\hline Month ending & $\begin{array}{c}\text { WFM } \\
\text { (kg DM/ha/day) }\end{array}$ & SE & $\begin{array}{c}\text { Observed } \\
\text { (kg DM/ha/day) }\end{array}$ & SE \\
\hline 30-J un-99 & 8.5 & 1.3 & 7.0 & 11.4 \\
31-J ul-99 & 10.0 & 1.3 & 39.0 & 30.4 \\
30-Aug-99 & 15.4 & 2.2 & 32.0 & 18.4 \\
30-Sep-99 & 48.0 & 4.0 & 92.0 & 15.0 \\
30-Oct-99 & 76.0 & 5.9 & 76.0 & 37.2 \\
30-Nov-99 & 75.0 & 6.0 & 75.0 & 22.4 \\
31-Dec-99 & 64.0 & 4.9 & 101.0 & 37.3 \\
28-J an-00 & 50.0 & 3.1 & 56.0 & 62.3 \\
28-Feb-00 & 35.0 & 6.4 & 21.0 & 40.6 \\
29-Mar-00 & 44.0 & 3.8 & -13.0 & 21.1 \\
29-Apr-00 & 37.0 & 3.6 & 31.0 & 25.4 \\
29-May-00 & 23.0 & 2.0 & 32.0 & 25.0 \\
\hline
\end{tabular}

Figure 1 1999-00 observed weekly, fortnightly average and monthly average pasture growth rates for the Waikato.

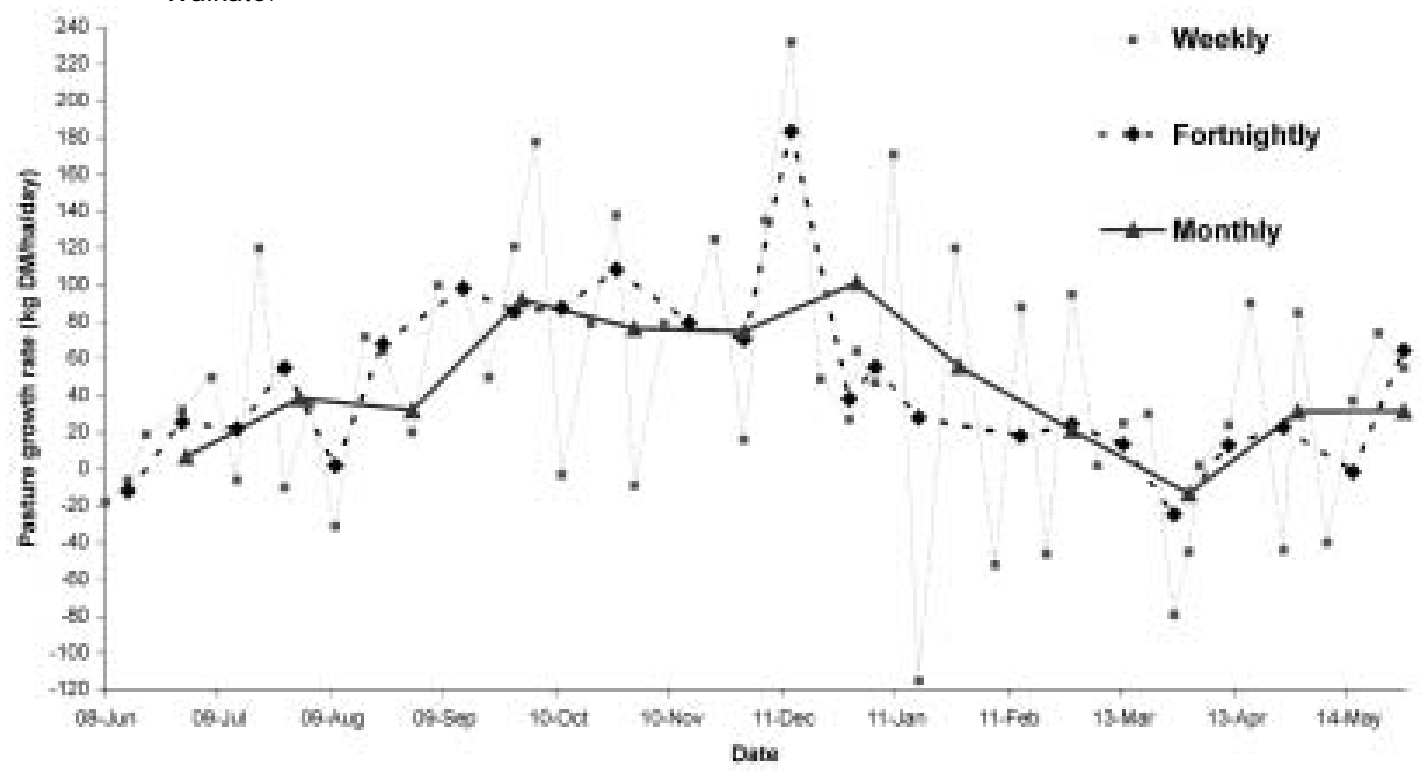


observations were averaged fortnightly (Figure 1).

The WFM calculates daily pasture growth rates and these values demonstrate fluctuations (Figure 2A). The fluctuations were not as large as those in the observed pasture growth rate data. For example, values ranged from $133 \mathrm{~kg} \mathrm{DM} / \mathrm{ha} /$ day on 12 Oct to $63 \mathrm{~kg} \mathrm{DM} / \mathrm{ha} /$ day on 13 Oct. When these daily values were averaged weekly, fortnightly or monthly, relatively smooth curves were obtained for pasture growth rate (Figure 2B). The predicted rates were close to the average monthly values, but were $30 \%$ to $50 \%$ of the observed rates in spring, and $140 \%$ to $150 \%$ of the observed in autumn (Figure 3 ). The standard errors for the monthly predicted rates are considerably smaller than those of the observed rates (Table 1).

\section{Discussion}

The results demonstrate that increasing the frequency of

Figure 2 Pasture growth rates for 1999-00 for the Waikato predicted by the Whole Farm Model. (A) Daily. (B) Weekly, fortnightly and monthly average.
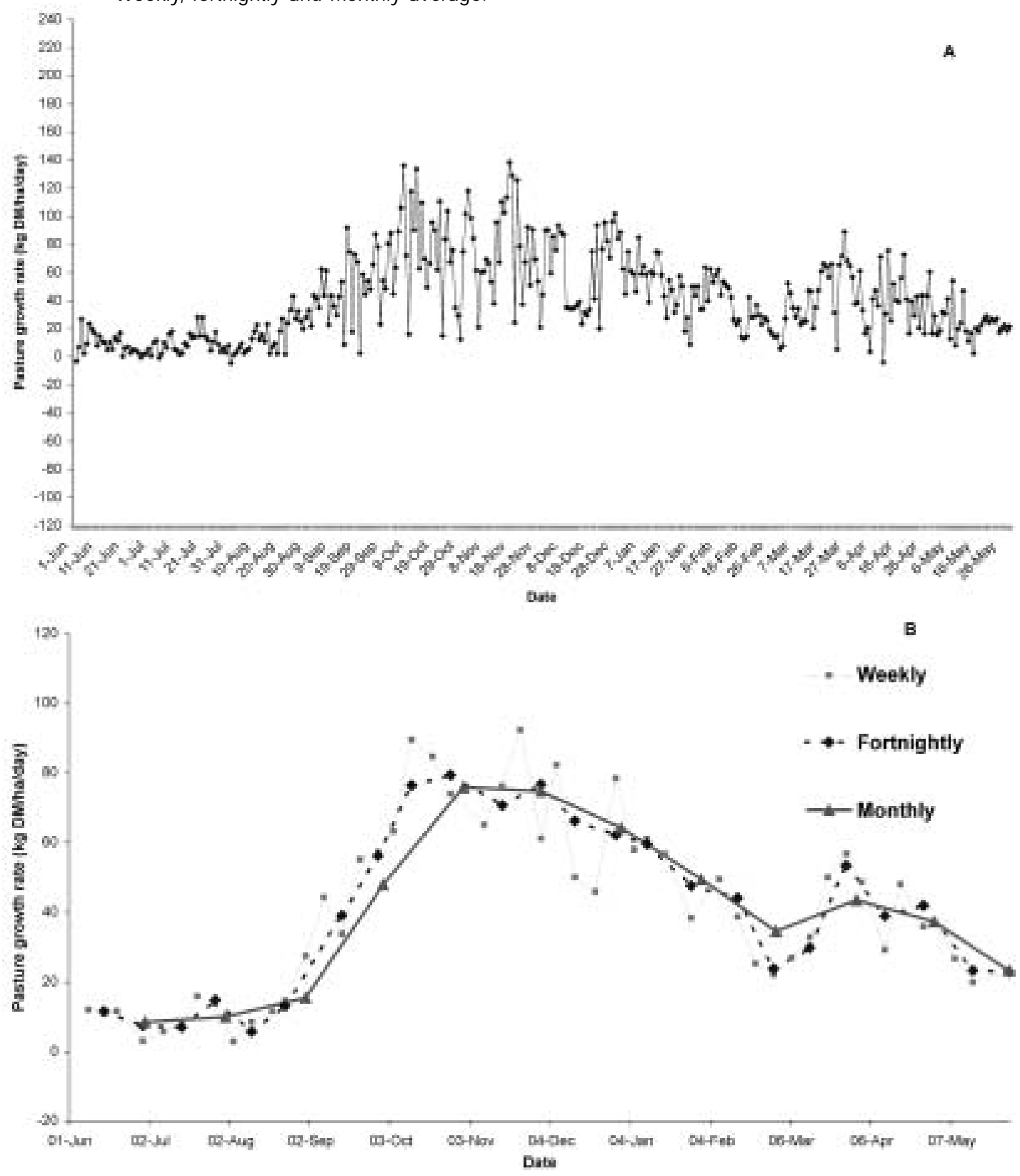
Figure 3 1999-00 monthly average pasture growth rates for the Waikato, predicted by the Whole Farm Model and from pasture assessment. Bars indicate standard error.

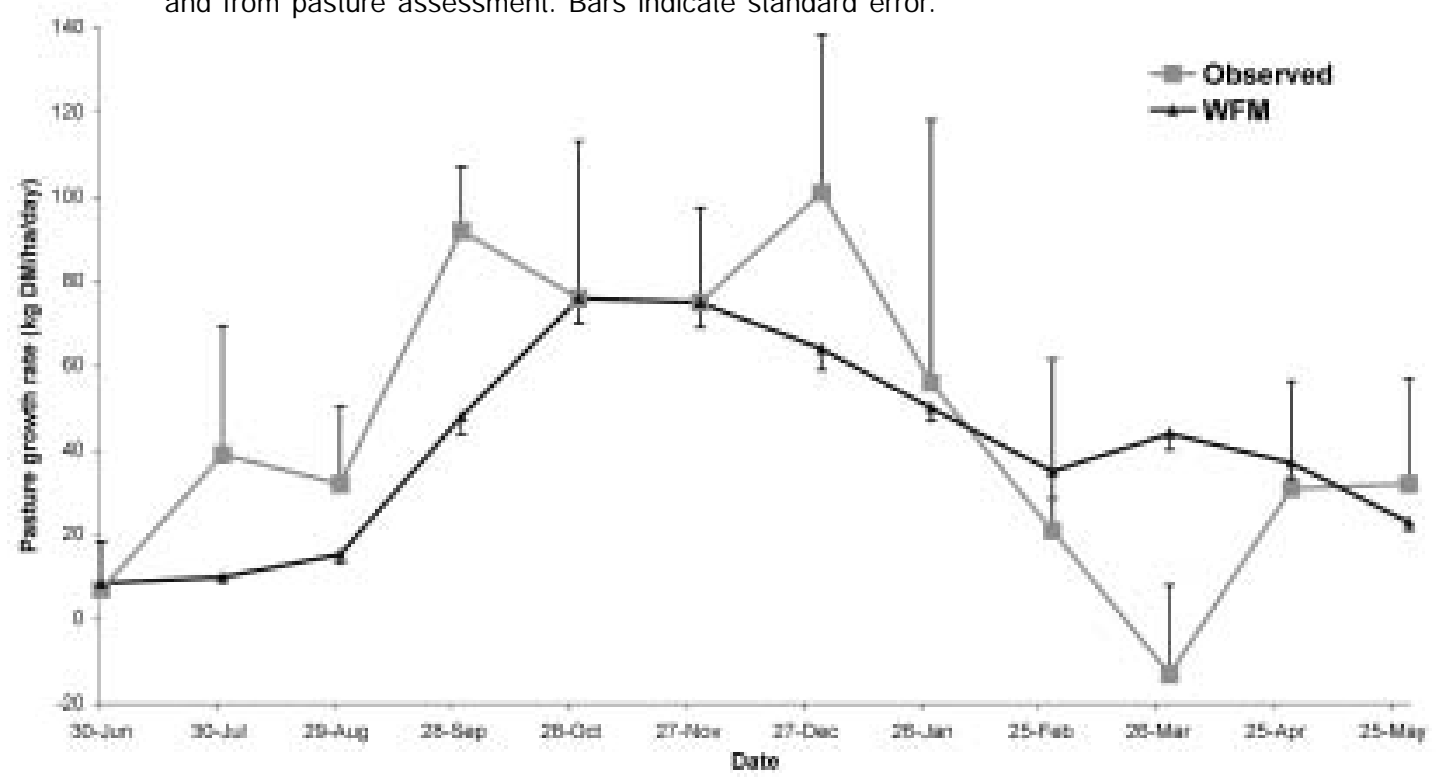

pasture assessment allows more accurate estimates of pasture growth as fluctuations are removed by averaging over a given period. Because the WFM calculated pasture growth daily, the standard error for the predicted monthly average is less than that of the observed monthly average (based on weekly observations). Weekly visual pasture cover assessment result in large fluctuations in pasture growth rates.

The size of the fluctuation is influenced by the variety of paddocks assessed (e.g. whether they were recently grazed or closed for conservation), climate, technique used and human error. The effect of the variety of paddocks assessed and climate on pasture growth fluctuation is assumed to be the same for the WFM predicted values and the observed values as they both used the same paddock and climate data. Technique used and human error remain the likely cause of differences in fluctuation of pasture growth between the observed data and the WFM predictions. An error of at least $200 \mathrm{~kg}$ $\mathrm{DM} / \mathrm{ha}$ when a trained calibrated operator visually estimates pasture cover has been reported in previous research (Piggot \& Morgan 1985). Such a difference between the actual value for pasture cover and estimated pasture cover can result in the large fluctuations shown in the observed weekly pasture growth rates. For example, an increase in pasture cover of $300 \mathrm{~kg} \mathrm{DM} / \mathrm{ha}$ over one week is equivalent to a pasture growth rate of $43 \mathrm{kgDM} /$ ha/day. If the operator was to over-estimate pasture cover at the end of the week by $200 \mathrm{~kg} \mathrm{DM} / \mathrm{ha}$, then the calculated pasture growth rate would be $71 \mathrm{kgDM} / \mathrm{ha} /$ day. The use of the WFM to predict weekly estimates of pasture growth rate based on daily calculation removes the confounding effect of human error and poor technique.

Differences between the WFM predicted values and the observed values may be due to several factors in addition to frequency of assessment. The use of nitrogen fertiliser in the observed farm (up to five applications of $40-50 \mathrm{kgN} / \mathrm{ha}$ over the year) is not explicitly modelled in the WFM at the current time. Pasture senescence, and changes in species composition (lack of clover in the observed pastures) may not be adequately modelled in the WFM. These factors are currently being investigated in the WFM.

With refinement and appropriate climate knowledge, the WFM could be used to make weekly predictions of pasture growth rates. One advantage of increased frequency of prediction is the opportunity to detect change from planned targets earlier in order to implement management corrections (De Freitas et al. 1993). By predicting likely changes in pasture growth under different climatic conditions over critical periods it could be used with software, such as FeedPlan (Blackwell et al. 2002) to aid management of feed supply on dairy farms.

\section{Conclusions}

Pasture growth rate determined on any single week can vary several-fold from the monthly average. The variation can be reduced by more frequent pasture assessment. On-farm estimation of pasture growth is often limited to weekly pasture assessments, whilst the Whole Farm Model calculates pasture growth on a daily basis. Fluctuations in pasture growth that are attributable to human and technique error may be reduced by improved 
techniques of assessing pasture cover that allow more frequent assessment with minimal human input. Once well validated and refined, the Whole Farm Model could be used to predict likely changes in pasture growth rate for different climatic conditions over critical periods to aid feed budgeting on dairy farms.

\section{REFERENCES}

Baars, J.A; Rollo, M.D. 1987. Predictive use of a pasture production model on commercial farms: some examples. Proceedings of the New Zealand Society of Animal Production 47: 39-42.

Blackwell, M.; Prewer, W.; Dawson, J.; Folkers, C.; Thomas, J.; Penno, J.; Wastney, M. 2002. Feedplan: A software tool for feed budgeting. Proceedings of the Ruakura Farmers' Conference 54: 48-49.

Bright, K.P.; Sherlock, R.A.; Lile, J.A.; Wastney, M.E. 2000. Development and use of a whole farm model for dairying. pp 382-389. In: Applied complexityfrom neural nets to managed landscapes. Eds. Halloy, S.; Williams, T. New Zealand Institute for Crop and Food Research, Christchurch, New Zealand.

Davis, K.L.; Thomson, N.A.; McLean, N.R.; McCallum, D.A.; Hainsworth, R.J.; Wards, A.J.; Barton, R.G. 1998. Pasture growth on dairy farms in the Golden Bay and West Coast of the South Island. Proceedings of the New Zealand Grassland Association 60: 9-14.

De Freitas, M.B.; Hurley, E.M.; Parker, W.J. 1993. The use of indicator paddocks to improve the quality of information for grazing management. Proceedings of the New Zealand Grassland Association 55: 93-96.

Lile, J.A.; Blackwell, M.B.; Thomson, N.A.; Penno, J.W.; Macdonald, K.A.; Nicholas, P.K.; Lancaster J.A.S.; Coulter, M. 2001. Practical use of the rising plate meter (RPM) on New Zealand dairy farms. Proceedings of the New Zealand Grassland Association 63: 159-164.

Lile, J.A.; Bright, K.P.; Palliser, C.C.; Prewer, W.E.; Wastney, M.E. 2002. Modelling dairy production in different regions of New Zealand. Proceedings of the New Zealand Society of Animal Production 62:7-11. McCall, D.G. 1984. A systems approach to research planning in North Island hill country. PhD thesis. Massey University, New Zealand.

Macdonald, K.A.; Penno, J.W. 1998. Management decision rules to optimise MS production on dairy farms. Proceedings of the New Zealand Society of Animal Production 58: 132-135.

Macdonald, K.A.; Penno, J.W.; Nicholas, P.K.; Lile, J.A.; Coulter, M; Lancaster, J.A.S. 2001. Farm systems - Impact of stocking rate on dairy farm efficiency. Proceedings of the New Zealand Grassland Association 63: 223-227.

Moir, J.L.; Scotter, D.R.; Hedley, M.D. 2000. A climate-driven, soil fertility dependent, pasture production model. New Zealand Journal of Agricultural Research 43: 491-500.

Piggot, G.J.; Morgan, H.M. 1985. Visual assessment of dry matter yield of pastures on dairy farms. New Zealand Journal of Experimental Agriculture 13: 219-224.

Roberts, A.H.C.; Thomson, N.A. 1984. Seasonal distribution of pasture production in New Zealand XVIV. Central Taranaki. New Zealand Journal of Experimental Agriculture 12: 93-101.

Thomson, N.A.; Upsdell, M.P.; Hooper, R.; Henderson, H.V.; Blackwell, M.B.; McCallum, D.A.; Hainsworth, R.J.; Macdonald, K.A.; Wildermoth, D.D.; Bishop-Hurley, G.J.; Penno, J.W. 2001. Development and evaluation of a standardised means for estimating herbage mass of dairy pastures using the rising plate meter. Proceedings of the New Zealand Grassland Association 63: 149-158.

Wastney, M.E.; Palliser, C.C.; Lile, J.A.; Macdonald, K.A.; Penno, J.W.; Bright, K.P. 2002. A whole-farm model applied to a dairy system. Proceedings of the New Zealand Society of Animal Production 62: 120123.

Woodward, S.J.R. 1999. Validating a model that predicts daily growth and feed quality of New Zealand dairy pastures. pp 777-782. In: Proceedings of the International Congress on Modelling and Simulation (MODSIM 99) Vol. 3. Eds. Oxley, L.; Scrimgeour, F.; Jakeman, A. Waikato Management School, The University of Waikato, Hamilton, New Zealand. 